\title{
A Cognitive-Semantic Study of Conceptual Metaphors in English News Reports
}

\author{
Hoshang Farooq Jawad ${ }^{1,}$ Aram Kamil Noori ${ }^{2}$ \\ ${ }^{1}$ Department of English, College of Basic Education, University of Sulaimani, Sulaimani, Kurdistan Region - F.R. Iraq \\ ${ }^{2}$ Institute of Training and Educational Development, Sulaimani, Kurdistan Region - F.R. Iraq
}

\begin{abstract}
This study explores how the development of the conceptual metaphor theory opened new horizons into the way language can be manipulated in the portrayal of the world and our immediate and distant environment of which news, including political news are part. Moreover, political news is the most pervasive type we continually come into contact in our daily communication. Conceptual metaphor is a relation between two conceptual domains, namely, source domain which is concrete, and target domain which is abstract. For example, ARGUMENT IS WAR. We conceptualize and understand "ARGUMENT", the target domain, in terms of "WAR", and the source domain via a process called "mapping". The goal of the study is to carry out a cognitive analysis of conceptual metaphors used in political news reports and how reports of the two newspapers construe political issues reflected in their reports. The study has hypothesized that conceptual metaphors are as common in the news reports of the political register as they are in daily conversational language. However, some types of conceptual metaphors are argued to be more common than others in the register in question whilst all the conceptual metaphors are seen as having experiential bases which are related to our life experiences.
\end{abstract}

Key Terms - conceptual metaphor, source domain, target domain, invariance principle, news reports.

\section{INTRODUCTION}

Metaphors are pervasive not only in language, but in thought and action in human beings' everyday life as well (Lakoff \& Johnson, 1980:3). They are an integral part of human life and have been explored and studied since antiquity. Lots of linguistic scholars have striven to find the secrets of metaphor from Aristotle until now. In this paper, the researchers seek to explore the nature and types of metaphors in general. Moreover, the conceptual metaphor framework developed by Lakoff has attracted the attention of linguists and scholars ever since it came out early 1980s. This is mainly due to the novel insight it provides us into the exploration of metaphors from a completely different perspective than the traditional. However, political news forms the newest pervasive type of written discourse we encounter in our daily lives which contain a considerable number of conceptual metaphors. Hence, the present study is set to explore how conceptual metaphors are manipulated in political news by answering the following questions: Concerning the quantitative aspect of the study, the question is: How common are conceptual metaphors in English news stories of the written political register? Concerning the qualitative aspect of the study, the question is: What types of conceptual metaphors are used in news stories in English newspapers? How conceptual metaphors are experimentally based on human beings' life experiences?

\section{The COGNITIVE VIEWS OF METAPHOR}

The term "metaphor" dates back to Greek which means "transference". From ancient Greek and Roman the term was used to transfer the meaning from one object to the other. The qualities of one attached to the other (Galperin, 1977:139). They viewed the metaphor as a sign of language embellishment. Metaphor style is different from the literal style usage of language as Cruse (2006:106) states that metaphor is "What distinguishes a metaphorical use of an expression is the relationship between its figurative meaning and its literal meaning. Metaphor involves a relation of resemblance or analogy". He highlights the difference between the literal and non-literal use of the expressions, striving to exhibit points of compatibility. Metaphor is one of the difficult issues facing the language learners while in the process of learning because of its compositional meanings.

The study of metaphor is primarily conceptual and conventional. Part of our ordinary system of thought and language can be traced back to Michael Reddy's classic paper, "The conduit metaphor". Reddy (1979) explains that the focal point of metaphor is thought, not language. He was the first to demonstrate it by analyzing it from various perspectives and

Journal of University of Human Development

Volume 7 No. 1(2021); DOI: 10.21928/juhd.v7n1y2021.pp12-34

Regular research paper: Received 27 September 2020; Accepted 11 November 2020; Published 18 January 2021

Corresponding author's e-mail: hoshang.farooq@googlemail.com, aramuniv2003@gmail.com

Copyright (C2021 Hoshang Farooq Jawad, Aram Kamil Noori. This is an open access article distributed under the Creative Commons

Attribution License (CC BY-NC-ND 4.0) 
showing generalizations using numerous examples (Lakoff, 1993:203).

Later George Lakoff and Mark Johnson (1980) followed in Reddy's footsteps about metaphor and developed his thoughts in a very systematic way. George Lakoff and Mark Johnson pinpoint that metaphor is projection and mapping process across conceptual domains, namely source and target domains. They substitute "vehicle" and "tenor," or "primary" and "secondary," for the terms "source domain" and "target domain." Part of the source domain is mapped onto the target domain in, in a one-way "transaction"(Abrams, 1999:157).

In the cognitive linguistic view, metaphor is conceptualized as comprehending a conceptual domain in terms of another conceptual domain. Kovecses (2010:4) explains that source is the domain from which we draw metaphorical expressions, and the target domain is the domain from which we conceive the use of source domain. For example, when we say Life is a journey. We see life in terms of journey. Journey has obstacles, and life does and so on.

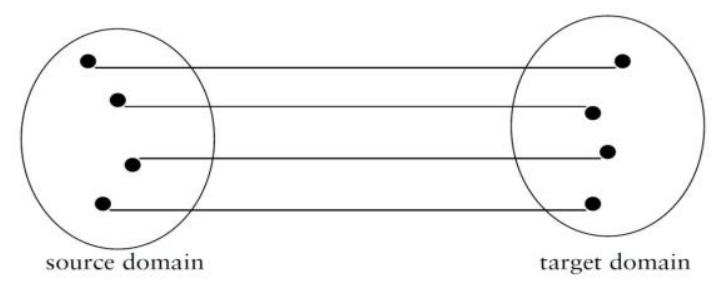

Figure 1

The small black circles in the diagram represent concepts and the connecting lines represent cross-domain mappings (Evans, 2007:53).

Lakoff (1987:303) considers that both domains do not have preconceptual structure so that the metaphor can work i.e. conceptual metaphor is based upon two conceptual domains namely target domain and source domain, and it does not depend on preexisting seminaries between the two domains as it could be noticed in the case of traditional views.

\section{CONCEPTUAL MetaPhor THeORY}

George Lakoff and Mark Johnson were the first linguists cognitively working in the field of metaphor by publishing their seminal book Metaphors We Live By. But Zoltán Kövecses, Raymond Gibbs, Eve Sweetser, and Mark Turner later were involved in studying metaphors as well. Hence the cognitive semanticists developed Conceptual Metaphor Theory (CMT) (Evans, 2007:33).

The central idea behind CMT is the relation between the two domains, namely source and target domain whereby target domain can be understood via the source domain through correspondences between the two. Mostly source domain is concrete and familiar while target domain abstract and unfamiliar. An example of a conceptual metaphor is Life is a journey. Here, the source domain is that of journey and the target domain - what the metaphorical expression refers to - is that of life (Cruse, 2006:31).
TABLE. 1

MAPPINGS FOR LIFE IS A JOURNEY

\begin{tabular}{ll}
\hline \hline JOURNEY= source domain & LIFE= target domain \\
\hline beginning of journey & Birth \\
end of journey & Death \\
reaching destination & Achieving aim \\
crossroads & Point of choice \\
\hline \hline
\end{tabular}

\section{Properties of CONCEPTUAl Metaphor}

Conceptual metaphor is not a sort of structure in language, in which it is arbitrary, but it has some principles and properties with which it can be recognized. Here are some of them:

\section{a) Pervasiveness}

According to Lakoff and Johnson (1980:7) metaphor is everywhere in language use, it is not only in language but it is in thought and action. Metaphor exists in every portions of life, for example, in thinking and performance, what humans do is actually metaphorical in nature. Metaphor is an integral part in humans' every second of life. Metaphors "also govern everyday functioning, down to the most mundane details". To clarify this feature related to metaphor, there are several examples proving metaphor to be pervasive. For example,

\section{ARGUMENT IS WAR}

- Your claims are indefensible.

- His criticisms were right on target.

- I demolished his argument.

- I've never won an argument with him.

- If you use that strategy, he'll wipe you out.

It is vital to know that we do not just talk about arguments in terms of war. We can actually win or lose arguments. We see the person we are arguing with as an opponent. We attack his positions and we defend our own. We gain and lose ground. (Lakoff \& Johnson, 1980:4). Arguments and wars are two different sorts of things -"verbal and discourse", both argument and war have connections with each other. One is understood in terms of another.

\section{b) Systematicity}

Systematicity is not only concerned with the finding point of comparison but with finding properties of source domain and target domain as well. Accordingly, both domains are put together so that metaphor can have internal logic (Saeed, 2009:348). Lakoff and Johnson (1980:7) claim that "metaphorical concept is systematic; the language we use to talk about that aspect of the concept is systematic". Linguistic metaphorical expressions are systematically bound with the conceptual metaphorical expression; their connections are not arbitrary and random. For instance, 


\section{TIME IS MONEY}

- You're wasting my time.

- I don't have the time to give you.

- How do you spend your time these days?

c) Cultural Coherence

Lakoff and Johnson (1980:22) refer to the point that cultural principles parallel metaphorical expressions. For example, UPDOWN metaphors correspond to some cultural ethics by which we live but not the other way around. Here are some more examples:

- "More is better" is coherent with more is up and good is up.

- "Less is better" is not coherent with them.

- "Bigger is better" is coherent with more is up and good is up.

\section{MORE IS UP}

- My income rose last year.

- The amount of artistic activity in this state has gone down in the past year.

- His income fell last year.

\section{GOOD IS UP}

- Things are looking up.

- We hit a peak last year, but it's been going downhill ever since.

- The quality of life is high these days.

d) Unidirectionality

Saeed (2009:350) supposes that "metaphors push the listener to transmit the properties from the source to the target domain". Conceptual metaphors work when the features are mapped through a one-way direction not the other way round as Evans and Green (2007:296) claim that "conceptual metaphors are unidirectional. This means that metaphors map structure from a source domain to a target domain but not vice versa". For example, while we conceptualise LOVE in terms of JOURNEYS, we cannot conventionally structure JOURNEYS in terms of LOVE: travellers are not conventionally considered to be lovers, or car crashes in terms of heartbreak and so on.

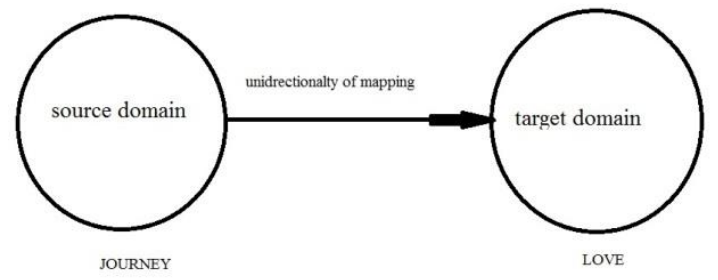

Figure.2 Unidirectionality of Mapping of LOVE IS A JOURNEY

\section{Classification of Conceptual Metaphor}

\section{A. Structural Metaphor}

Lakoff and Johnson (1980:14) define Structural metaphors as "cases where one concept is metaphorically structured in terms of another." So, the metaphorical expressions are dependent upon each other so that they can work. Kovecses (2010:37) explains that the structural metaphors can be viewed in a way that Target $\mathrm{A}$ is understood and structured via Source B and features of source domain is mapped onto target domain. For example, LIFE IS A JOURNEY. Life is structurally and metaphorically shaped in terms of journey.

\section{B. Orientational Metaphor}

This type of metaphor is concerned with the spatial perspective of the expression in what Lakoff and Johnson (1980:14) point out "these spatial orientations arise from the fact that we have bodies of the sort we have and that they function as they do in our physical environment". For example, HAPPY IS UP/ SAD IS DOWN.

HAPPY IS UP/ I'm feeling up.

- $\quad$ That boosted my spirits.

- $\quad$ My spirits rose.

\section{SAD IS DOWN}

- I'm feeling down.

- I fell into a depression.

\section{Ontological Metaphors:}

Ontological metaphors are shown when we experience with tangibles, we see intangible concepts such as emotions, ideas, psychological activities and states as concrete concepts (Liu, 2013:157). Kovecses (2010:38) points out that "we conceive of our experiences in terms of objects, substances, and containers, in general, without specifying exactly what kind of object, substance, or container is meant." Ontological metaphors have a physical world entity in the source and an activity (e.g., He put a lot of energy into his attack), emotion (e.g., He has fear) or idea (e.g., we have a problem) in the target (Ibáñez and Hernández, 2011:4).

\section{THE INVARIANCE PRINCIPLE}

Metaphorical mappings face problems in copying properties from source domains onto target domains. So, the problem, here, is which part of the source domain can be mapped onto the target domain. So that the process of mapping can stay away 
from this problem as Antunano (I999:38) diagnoses that "The only problem with this principle is that it does not show exactly what part of the source domain is the one that must be consistent with the structure of the target domain". Hereby, Lakoff (1993: 215) proposed a hypothesis called "The Invariance Principle"; wherein he states that "Metaphorical mappings preserve the cognitive topology (that is, the image schema structure) of the source domain, in a way consistent with the inherent structure of the target domain". That is to say, some properties of the source domain can be mapped onto the target domain but not all of them. For example, LIFE IS A JOURNEY, where elements of literal journeys are mapped onto the target domain of life in a consistent way; so that the start of a journey is mapped onto birth and the end of the journey is mapped onto death. The start of the journey will not be mapped onto a middle point in life, and difficult pathways will not be mapped onto easy periods of life.

\section{Procedures AND DATA COLLECTION METHOD}

Events happen every second and probably around us then reported and broadcast from various mass media. Indeed, not all the reports are important to us. We pay attention to the news reports per our preferences. Not all events are considered to be a news report but selective as far as the people are concerned as Conboy (2007:36) explains "News is the process of selection in which events are priotized according to a range of socially organized categories. This process is one which already tells us a great deal about the political positioning and the belief systems in specific mass media"

The research data analyzed in this study come from the two online versions of newspapers; one is from Britain which is the Guardian (2014-2015), and the other is from The United States which is the Washington Post (2014-2015). Ten samples from each are taken. Firstly, the metaphors extracted from the online newspapers are identified, accumulated, and schematized according to Lakoff and Johnson's metaphor theory. The study relies on two approaches of study, namely, quantitative and qualitative. After the data collection, both the qualitative and quantitative methods are applied to the samples taken from the newspapers. The quantitative analysis presents identifying all the conceptual metaphors in the data and also their types. The qualitative analysis seeks to focus on exploring the cognitive nature of conceptual metaphors used in the data and stating the most and the least common types of conceptual metaphors found in the news stories.

\section{DATA ANALYSIS}

\section{A. Quantitative analysis of conceptual metaphors}

From the output presented below, 172 conceptual metaphors can be tracked down from both The Guardian and Washington Post. Among the samples collected and analyzed then, we come across 14 widespread metaphors which pervade the English news reports as shown in the following table:
TABLE. 2

TYPES OF CONCEPTUAL METAPHORS USED IN THE DATA

\begin{tabular}{lcc}
\hline \hline Conceptual Metaphors & Count & Percentage \\
\hline SPATIAL & 59 & $34.30 \%$ \\
PERSONIFICATION & 19 & $11.04 \%$ \\
CAUSATION & 14 & $8.13 \%$ \\
TIME & 13 & $7.55 \%$ \\
CONTAINER & 11 & $6.39 \%$ \\
OBSTACLE & 9 & $5.23 \%$ \\
EXISTENCE & 8 & $4.65 \%$ \\
HUMAN & 8 & $4.65 \%$ \\
LINEAR SCALES & 5 & $2.90 \%$ \\
PSYCHOLOGICAL FORCES & 4 & $2.32 \%$ \\
TALK & 4 & $2.32 \%$ \\
AGREEMENT & 4 & $2.32 \%$ \\
IMPORTANCE & 4 & $2.32 \%$ \\
SUBSTANCE & 4 & $2.32 \%$ \\
Other metaphors & $6.48 \%$ \\
\hline \hline
\end{tabular}

From the Table.3, you can see that SPATIAL metaphors take up the largest proportion in the data in a way that 59 of the conceptual metaphors are spatial metaphors which make $34.30 \%$ of the distribution. Following that is PERSONIFICATION metaphor, and 19 samples can be found which occupy $11.04 \%$ of the data analysed. After that, the CAUSATION metaphors comprise $8.13 \%$ of the data which amounts to 14 expressions. Next, the TIME metaphors which contain 13 metaphorical expressions calculate $7.55 \%$ of the data. The metaphorical expressions which include SPATIAL, PERSONIFICATION, CAUSATION, and TIME cover a wide range of the data compiled from the English news of political issues. This indicates that these conceptual metaphors are more pervasive comparing to others. They take in the first proportion of the data.

The second widespread conceptual metaphors are CONTAINER, OBSTACLE, EXISTENCE, and HUMAN. The conceptual metaphors are distributed in a way that 11 for CONTAINER, 9 for OBSTACLE, 8 for EXISTENCE, and 8 for HUMAN in order. They take percentages $6.39 \%$, \%5.23, $4.65 \%$, and $4.65 \%$ respectively.

The lowest proportions of the conceptual metaphors amassed in the data are rightly assigned to LINEAR SCALE, PSYCHOLOGICAL FORCES, TALK, AGREEMENT, IMPORTANCE, and SUBSTANCE. The numbers 5, 4, 4, 4, and 4 represent the metaphorical expressions respectively. So do the percentages viz $2.90 \%, 2.32 \%, 2.32 \%, 2.32 \%, 2.32 \%$, and $2.32 \%$. 
There are some sporadic conceptual metaphors which can be found in the data such as RELATIONSHIP, REFORM, DEBATE, MOVEMENT, MISSION, and SIZE. Each of them has one conceptual metaphor in the data. This indicates that conceptual metaphor is pervasive in every aspect of speech even though they contribute a minor share to the data.

\section{B. Qualitative analysis of conceptual metaphors}

\section{Spatial Metaphor}

Based on our interaction with life, we see that spatial metaphors are bipolar such as in-out, up-down, and centre-periphery works because they are coherent with each other. For example, HAPPY is coherent with UP, and SAD is coherent with DOWN.

- I am feeling up. (HAPPY)

- I am feeling down. (SAD)

The samples found in the data present these spatial metaphors (HIGH STATUS IS UP, LOW STATUS IS DOWN, MORE IS UP, LESS IS DOWN, RISING IS UP, and FALLING IS DOWN).

\section{HIGH STATUS IS UP, LOW STATUS IS DOWN}

Source domain: up, down Target domain: high status, low status

Cultural background of any society provides different ranking systems to people or things in its environment. It may classify its members according to occupation, socioeconomic position, gender, age, etc. Therefore, the power and authority differ from one to another. Someone from high status has more power than someone who is low in status. So, there are different ranking systems in society from the high system like the government to the lowest one like family such as father has the highest rank and then to the mother and the children. Other examples, the prime minister has power over the ministers in his administration. The same in a group, the leader has the power over the members. The examples below display the ranking system in society.

1. The Israeli prime minister's surprising announcement that he will address a joint meeting of Congress in early

March is straining relations between Israel and its closest ally (Washington Post, 22 January 2015).

2. The mood is downbeat and sober compared to the tantalising hopes awakened in Vienna with the arrival of US secretary of state John Kerry to meet face-to-face with his Iranian counterpart, Mohammad Javad Zarif, accompanied by five other foreign ministers from major powers (The Guardian, 15 December 2014).

3. -We are surprised by the position of the Iraqi interior ministry in light of the fact [Dulaimi] said that she was married to Ibrahim al-Samarai, who is also known as Abu Bakr al-Baghdadi, \| said a Lebanese security official (The Guardian, 3 December 2014).
4. House Minority Leader Nancy Pelosi (D-Calif.) said during a news conference Thursday that it is "out of the ordinary" for a House speaker to invite a world leader to a joint session of Congress without consulting leadership from the other party (Washington Post, 26 January 2015).

5. Since some laws, although almost exclusively applicable to England, have a knockon effect for Scotland as the junior economic partner in the union (The Guardian, 16 December 2014).

By paying attention to the above-mentioned examples, we find different levels of status in the corpus -at the level of the highest-ranking system of the government then to the level of the ministers and then to the level of institutions and parties. In example (1), the status is at the top level of the government. The person who is in charge of this level has the power and authority over members below him. For example, the president has the power over any other officials who work in the governmental instituitions, and as well as the prime minister and supreme leader have over the officials below them.

In example ( 2 and 3 ), the ranks are at the level of the ministers. The US secretary of state John Kerry in his ministry is higher than the officials in his ministry; they are at Kerry's command, they obey his orders. But Kerry has a counterpart in another country outside of his country; the officials there are not at his command. His counterpart has the same power as Kerry over the people below his rank. The Iraqi interior ministry has the authority over their lower-ranking officials. They have the ability to give orders and the people who are junior than them obey their orders and carry out their duties according to the instructions come with the command.

In examples (4 and 5) given above such as junior economic partner and House Minority Leader, we conceive that both have low status comparing to their rival opponents. According to Longman Dictionary 2009, The House Minority Leader is the president of a political party in congress that has fewer politicians than the leading party. Majority leader is the person who organizes the members of the political party that has the most people elected, in the US House of Representatives or Senate. Here, the Minority Leader has less power than the majority leader due to the position they have in the House of Representatives.

From the examples considered above, we can establish two points; firstly, someone from a higher position enjoys power and high status while someone from a low position has less power and authority and is required to comply with instructions. Secondly, high status is coherent with being up, and low status corresponds with being down.

\section{MORE IS UP, LESS IS DOWN}

These two metaphors in the examples show two things, one is verticality and the other is quantity. Both have a coherent relationship with each other. When the quantity of a material 
increases, it usually goes upward, while decreasing, it is downward.

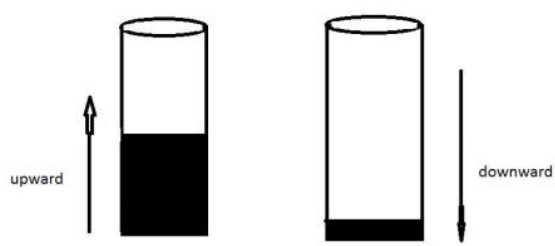

Figure.2 MORE IS UP, LESS IS DOWN

1. Such a move, Obama has said, would cause the delicate talks with Iran to fail and increase the likelihood of armed conflict (Washington Post, 22 January 2015).

2. On Labour's analysis, if the Met had to cut its budget by $£ 100 \mathrm{~m}$ in $2016-7$, it would have to trim police numbers by 1,298 if it relied on officer headcount reductions alone to achieve that level of saving. If the same level of saving was required for each of the four years, 194 posts could be at risk (The Guardian, 22 December 2014).

In example (1), the likelihood of armed conflict will rise up when the quantity is increased. But when it is decreased, it is falling down as shown in example 1(2). When the headcount is reduced, it will have low numbers then.

\section{FALLING IS DOWN, RISING IS UP}

Source domain: down Target domain: falling

Falling is usually down oriented. The direction is downward. This is what we really see in the world around us, this is what we experience in life. Falling is coherent with down orientation. Consider the followings:

1. However, the French proposal is seen by Palestinians as falling far short of their demands (The Guardian, 15 December 2014).

2. In August, the terror threat level in Britain was raised from - substantial to - severe (Washington Post, 23 January 2015).

In example (1), the Palestinians set a level for their demands; they want the demands to reach that level, but the French proposal does not go up so as to reach the level, but from Palestinians' angle, it is falling down. In example (2), the threat level goes upward from substantial to severe.

Through the two examples above, we arrive at a point that falling is coherent with down orientation-it does not go to the opposite extreme, and rising is coherent with up orientation.

\section{Personification Metaphor}

Personification is to see nonhuman objects as human beings. For example, the conceptualization of physical objects as humans as it is seen in the example (33)

- Cameras are not allowed in the courtroom (Washington

Post, 21 January 2015).
Cameras are comprehended as humans mapping the properties of human beings onto the physical objects "cameras". When people are not allowed to enter a building or a governmental place because they are special places and are only for very specific people for instance, prison buildings are not free for everyone to enter. Here, cameras are treated in the same way for not being allowed to enter the courtroom. Personification metaphor has various types in both newspapers The Guardian and The Washington Post.

\section{COUNTRIES ARE LEADERS}

Leaders: source domain Countries: target domain

Human beings have the feature of leading a group of people; they can lead them to anywhere they want. So, when this feature is mapped onto a nonhuman place, it plays the same role as humans do as in the example (34)

- But Republicans have challenged the actions, calling them unconstitutional. The lawsuit from 25 states, led by Texas, argues that the "unilateral suspension of the Nation's immigration laws is unlawful." (Washington Post, 23 January 2015).

Here, Texas plays the role of humans as it leads the lawsuit of the state. The feature of leading by humans has been transferred to Texas by a systematic process, in other words, mapping.

\section{INSTITUTIONS ARE SPEAKERS}

Speakers: source domain Institutions: target domain

Buildings become humans when the property of speaking is attached to the building especially governmental ones such as office, the white house, and library. These buildings become people, and even they answer and ask questions as seen in the below examples:

1. The White House on Thursday said that President Obama would not meet in Washington with Prime Minister Benjamin Netanyahu, who is in the midst of an election campaign. - We want to avoid even the appearance of any kind interference with a democratic election, || said White House spokesman Josh Earnest (Washington Post, 22 January 2015).

2. The Guardian reported that the Met needed to find an extra $£ 800 \mathrm{~m}$ of cuts in the next budget period, from 2016-2020 (The Guardian, 22 December 2014).

In examples (1 and 2), The White House says something or delivers a speech and it gives a report about Obama just like humans report on occasions, so this feature is mapped onto the governmental institution-The White House. The guardian is regarded as a reporter that reports on events happened somewhere.

\section{INSTITUTIONS ARE DECISION-MAKERS}

Decision-makers: source domain Institutions: target domain 
Decision-making is the feature of human beings, and it does not belong to any creatures or inanimate being in the world because decision-making relates to logic, and this logic is only the distinctive feature of human beings who are distinguished from any other creature in this universe. In the examples below institutions are presented to make decisions on various occasions:

1. It is not the first time spectators have shouted objections to the court's Citizens United decision, and courtroom security was increased last year after someone took and posted online video of a bit of an oral argument (Washington Post, 21 January 2015).

2. Scott Pruitt, Oklahoma's attorney general, said Monday he was asking the U.S. Supreme Court to postpone three executions in his state that are scheduled over the next six weeks, with the first set for Thursday (Washington Post, 26 January 2015).

In example (1), the court, which is a governmental institution, made a decision about citizens, but the spectators raised the objections to the court's decision. Here, even the spectators treat the court as a human that can respond to the reactions of the opposite people, and it can hear the arguments to have its say on the current situations that has to give as in example (2).

In the above examples the characteristics of humans are mapped onto the institutions receiving the properties such as making decisions, postponing executing prisoners, and cancelling a process.

\section{PLACES ARE PSYCHOLOGICALLY AFFECTED}

Psychologically affected: source domain Places: target domain

Places, like humans, involve psychological effects when facing difficult situations. They are worried about how to deal with a sudden situation the same way as humans do when they want to decide to do something; they are hesitant and afraid to face a negative result.

1. North Korea was so worried that Kim would be personally named in the ICC referral that it offered Darusman an opportunity to visit North Korea if the leader's name was left out of the resolution. Pyongyang had previously declined to extend such an invitation. Darusman, who has never been to North Korea, rejected the offer (Washington Post, 23 January 2015).

2. China has faced Western-backed provocations from neighboring countries over disputes in the East and South China seas (Washington Post, 2 February 2015).

Considering the above the examples, we understand that places, like humans, are psychologically influenced by the environment in which they exist. Psychological states are human nature. Humans become angry, sad, happy or they feel disappointed, etc. these features are mapped onto the places to place the humans' role. In example (1), North Korea was worried; it was psychologically affected with the situation exits. In example (2), China involves a situation which is unpleasant that makes China feels upset and angry.

\section{PLACES ARE PRISONERS}

Source domain: prisoners Target domain: places

Places are viewed as prisoners that can be released or liberated, captured or recaptured. Humans are put into prison due to a decision made by a judge because that person from the perspective of law in that area has committed a crime; therefore she/he is captured by police and then sent to prison, or that person may be captured by a group of people out of the law in the area or the state, and the government try to release them by force. In the below example, places face the same situation as humans do.

1. Peshmerga forces launched an operation to liberate some important areas in Sinjar and Zumar at 7am (04.00 GMT),॥ a peshmerga brigadier general said (The Guardian, 17 December 2014).

2. Yazidi fighting units that were formed in the wake of the August attack have struggled to control land in the Sinjar area and retreated to the mountain once again in September (The Guardian, 17 December 2014).

In example (1), peshmerga forces are prepared to free the areas from ISIS's control because ISIS has already captured these areas. The rest of the examples are the same, ISIS has taken control of the areas namely Sinjar, Kobani, and other areas. Here, these examples signal that features of humans are mapped onto the places.

\section{Causation Metaphor}

Causation is the process in which the participants are conceptualized as different kinds of forces involved in a way that the agent acts on the patient (affected entity) in many different ways such as change of state, causing to move, etc. Here is a list of causation metaphors discovered in the data:

\section{CAUSES ARE FORCES}

Forces have the quality of changing things or affairs from one state into another. Causes, in the same way, have the same feature onto which they are mapped. Accidents happen due to various motivators around them from different sides and push them into a state that is often unpleasant or discouraging as in the following examples:

1. Such a move, Obama has said, would cause the delicate talks with Iran to fail and increase the likelihood of armed conflict (Washington Post, 22 January 2015).

2. Complicating the issue are several factors, not least the fact that Israel is at the beginning of a prolonged election campaign that diplomats believe will lead to a hardening of Netanyahu's position (The Guardian, 15 December 2014). 
In example (1), the move is a factor to inject the delicate talks into a negative state which is a failure condition resulting in bad situation. In example (2), hardening of Netanyahu's position is the result of the prolonged election campaign, both the factor and the result are interlinked; one cannot be done without the other.

\section{CAUSED CHANGE IS FORCED MOTION}

Source Domain: motion, control causation, change

Causation metaphors to change the state of someone or something are like to move them into a place that is unfamiliar with and sometimes is unpleasant because it is inappropriate. In the following examples, we see these situations that humans or things engage in.

1. Kerry told reporters on Wednesday that the Israeli intelligence chief had made an impassioned case against new sanctions, saying that they would be akin to -throwing a grenade into the process. Such a position would have put him [Pardo] at odds with his prime minister (Washington Post, 22 January 2015).

2. The first protester caused the most disruption, as court police knocked over chairs in an attempt to reach her and drag her from the chamber (Washington Post, 21 January 2015).

In example (1), the position took the Israeli intelligence chief, Tamir Pardo, from his own condition into another as if he were held with hands and moved into a different place. Here, the causation adopts the qualities of transferring someone from a position to another, and it forces the entity to leave the place in which exist. In (2), the police dragged and pulled the first protester from her chamber into a place the police want. Here, the police make her to leave her place and settle in another position.

\section{CAUSES ARE MAKERS}

Source Domain: makers, inventors, creators

Domain: causes

Target

In some conditions, causes create situations like a person who invents new things out of the materials available at hand; they can use them and create different shapes out of them as they want. Causes can do the same as humans; they can create different situations from different factors. This is shown in the examples below:

1. The debate over the sanctions has already provoked a rare intervention from British Prime Minister David Cameron, who last week lobbied U.S. lawmakers to forgo any new punitive measures against Tehran (Washington Post, 22 January 2015).

2. Pardo, meanwhile, denied saying any such thing during a Jan. 19 meeting with the Americans. Instead, the Mossad director said he reiterated that - firm pressurell was needed - to bring about meaningful compromises from the Iranian side. \| (Washington Post, 22 January 2015).

In example (1), the debate, which is a factor, stimulates the intervention and creates a certain situation for Tehran. In example (2), firm pressure is could be used to make meaningful compromises that appear when it is activated and put to use.

\section{CAUSES ARE SUBSTANCES}

Source Domain: Substances Target Domain: Causes

At this time, causes are treated like substances that can be held and taken somewhere so that a state the factor wants can happen or come to view as seen in the example below:

- Speaking ahead of his trip to meet Kerry in Rome, Netanyahu said: - We will not accept attempts to impose unilateral measures upon us by a set date, at a time when radical Islam is spreading throughout the world. \| (The Guardian, 15 December 2014).

In the example, Netanyahu in his speech says that he will not accept anything that is imposed upon them. Here the factor is regarded as a substance that is put on somebody or somewhere. The features of substance are mapped onto the factor.

\section{Time Metaphor}

The concept of time is viewed in different ways according to the observer. The observer sees the time from different angles. The observer conceptualizes time in four versions as explained in the following with examples:

\section{TIME IS A MOVING OBJECT}

Source Domain: A Moving Object Target Domain: Time

The concept of time is considered to be a moving object with reference to the observer whose state is the present. In Figure.3, events leave the future and the observer. But in Figure.22B, events leave the past on the way towards the observer. Consider the examples from (93) to (97):

Figure 3

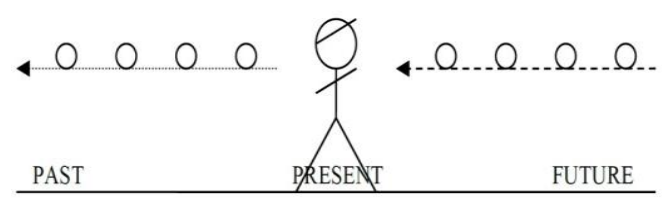

Figure.3 A TIME IS A MOVING OBJECT (leaving the observer) (Evans, 2013:4) 


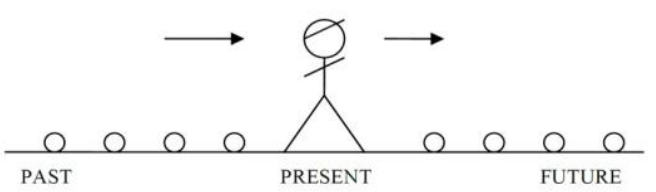

Figure.3 B TIME IS A MOVING OBJECT (towards the observer) (ibid.)

1. That report has come in for some scrutiny in recent days, however, since Shin Dong-hyuk, a star witness before the commission, admitted that there were some inaccuracies in his testimony (Washington Post, 23 January 2015).

2. Oklahoma's new policy involves a higher dose of midazolam, matching the amount that Florida has used since 2013 (Washington Post, 26 January 2015).

The occurrence of events shown in a way that one has happened sooner than the other as in earlier in which one event was prior to others vis-à-vis the observer's state. In example (1), the event in recent days happened in the nearest point to the observer. In example (2), the time of the event has a starting point lasting to the time of the state in which the observer exits.

\section{TIME IS A SURFACE}

Surface: source domain Time: target domain

Time, here, is presented as a landscape or a surface on which moving objects walk or fly as it is depicted in Fig.4 In this case the prepositions like (on and over) play this role.

1. The White House on Thursday said that President Obama would not meet in Washington with Prime Minister Benjamin Netanyahu, who is in the midst of an election campaign. - We want to avoid even the appearance of any kind interference with a democratic election, $\|$ said White House spokesman Josh Earnest (Washington Post, 22 January 2015).

2. Over the weekend, the head of Israeli intelligence also discussed the impact of new sanctions with a delegation of visiting U.S. senators (Washington Post, 22 January 2015).

In the examples (1 and 2), Thursday and the weekend are conceptualized as a ground. One states the condition of the starting point of the meeting on Thursday and the other signals the duration that lasts along the weekend.

\section{TIME IS A PATH}

Path: source domain

Time: target domain

The concept of time is viewed as a passage or a path that events move along it either from the past to the future or the other way around, as it is seen in:
1. The officials say air strikes since mid-November have killed senior and mid-level leaders as well as about 1,000 fighters, particularly around the fiercely contested Kurdish town of Kobani on the Syrian-Turkish border (The Guardian, 19 December 2014).

2. Internationalisation face losing their jobs by the end of the decade as part of George Osborne's plans to shrink the size of the state, according to a Labour analysis of figures compiled by the House of Commons library (The Guardian, 22 December 2014).

In the example (1), the killing occurred in the middle of the month November in which November is depicted as a path and the observer saw the event moving until it reaches the middle of the path then it occurred. In example (2), the event took place when it arrived at the end of the path.

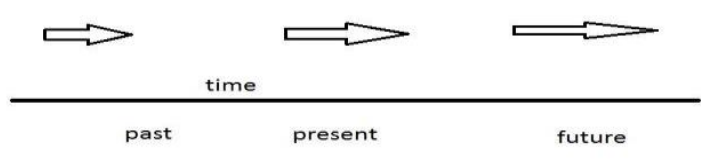

Figure.4 TIME IS A PATH

\section{TIME IS A CONTAINER}

Container: source domain Time: target domain

Time is conceptualized as a bounded object having the capacity of taking hold of things that we put in and take out, and the prepositions like (in, to, into) play this role in container metaphors as it is shown in the following figure:

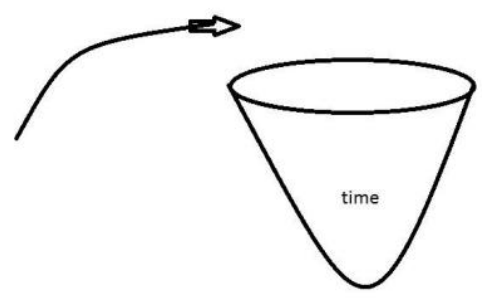

Figure.5 TIME IS A CONTAINER

1. The Israeli prime minister's surprising announcement that he will address a joint meeting of Congress in early March is straining relations between Israel and its closest ally (Washington Post, 22 January 2015).

2. In August, the terror threat level in Britain was raised from — substantial to —-severe," (Washington Post, 23 January 2015). 
In the examples (1 and 2), the time (March and August) are regarded as bottles or pots and the events characterized as being objects that we put into the bottle.

\section{TIME IS A DESTINATION}

\section{Source Domain: Destination \\ Time: target domain}

In the following example, Tuesday is presented as destination because the duration of the event lasts until a point in the future which is Tuesday. That is to say, Tuesday is the line on which the event continues to exist.

- The filing deadline is Tuesday (Washington Post, 26 January 2015).

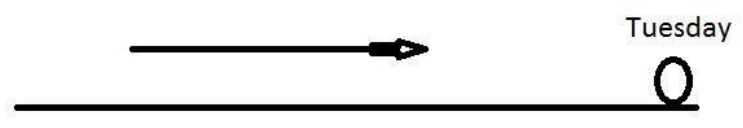

Figure.6 TIME IS A DESTINATION

\section{TIME IS SUBSTANCE}

Source Domain: Substance

Target domain: Time

Time is conceptualized as substance. The substance can be shaped in a way the user wants to, that user can reshape or extend it so that the area of the substance could be enlarged or produce many different shapes from this substance. Here, time could be extended like substance as shown in the example below:

- $\quad$ The deadline was extended until the beginning of July 2015 , with the aim of agreeing over a framework deal by March 1(The Guardian, 15 December 2014).

The end of the time appointed is extended just like the substance enlarged.

\section{Container metaphor}

Container metaphor is the concept which is considered as a bounded region that has in-out dimension. Here, there are two patterns of the container schema. First, when an item is in the container, and when an item is outside the container. Second, when the item moves to the inside of the container, and when the item goes out from the container.

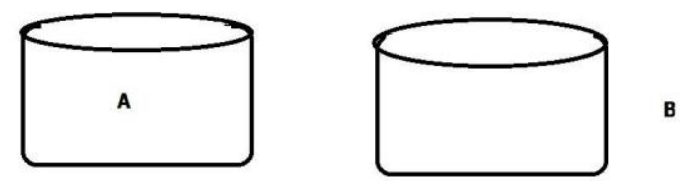

Figure.7A Container metaphor (Static version)

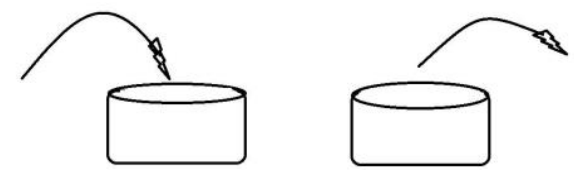

Figure.7B Container metaphor (Dynamic version)

\section{PLACES ARE CONTAINERS}

Source domain: Containers Target domain: Places

Places are conceptualized as containers - as having an in-out orientation. They are bounded regions where things go in and go out from or things are put in them. The prepositions such as (to and into) represent motion to the container while the prepositions such as in, inside, within, etc. represent the state of being in the container and outside and excluding represent the state of being outside the container. Consider the following examples:

1. TOKYO - Direct criticism of Kim Jong Un — whether through Hollywood films or international reports — has hit - a raw nervell in Pyongyang and should be continued, says the United Nations' special rapporteur on human rights in North Korea (Washington Post, 23 January 2015).

2. Since then, the continued devolution of further powers to Scotland and Wales has increased the call for matching devolution within England (The Guardian, 16 December 2014).

3. At the same time, US advisers are operating alongside Iraqi trainers in Anbar province, helping train and organise Sunni tribesmen into regular units to confront Isis (The Guardian, 19 December 2014).

The examples signal the state of being in the container resulting from the using prepositions like in and within. In (1), North Korea is conceptualized as a container having the ability to hold objects. In (2), England is the container for holding the call for matching devolution in the space of the bounded region which is England. US advisers' operation alongside Iraqi trainers occurs in the bounded region-Anbar as in (3).

\section{FORCES ARE CONATINERS}

Source domain: containers Target domain: Forces:

1. This time, the Iraqi government will seek to absorb the Sunni units into the national security forces (The Guardian, 19 December 2014).

2. At the same time, US advisers are operating alongside Iraqi trainers in Anbar province, helping train and organise Sunni tribesmen into regular units to confront Isis (The Guardian, 19 December 2014).

In both examples (1 and 2), the national security forces and regular units are containers to the Sunni units and regular units 
move. They flow into the forces as if they are considered to be bowls and pots into which liquid materials, like stream, flow

\section{PRODUCTS ARE CONTAINERS}

Source domain: containers: Target domain: products:

- TOKYO - Direct criticism of Kim Jong Un - whether through Hollywood films or international reports - has hit - a raw nervell in Pyongyang and should be continued, says the United Nations' special rapporteur on human rights in North Korea (Washington Post, 23 January 2015).

They are considered as a hollow space -things go in and go out. Hollywood films or international reports are seen as containers, and the criticism of Kim Jong Un, as a moving object, go either through Hollywood films or international reports.

\section{VOTE IS A CONTAINER}

Source domain: Containers

Target domain: vote

- The most radical of the three options involves non-English MPs being excluded from all votes of an English-only nature, including the budget (The Guardian, 16 December 2014).

All votes, in the example above, are seen as containers that things could be put in and taken out from them. Non-English MPs are considered as objects that are taken out from the container into the exterior side of the container-they are out outside the container.

\section{PROCESS IS A CONTAINER}

Source domain: containers: Target domain: process:

- Kerry told reporters on Wednesday that the Israeli intelligence chief had made an impassioned case against new sanctions, saying that they would be akin to throwing a grenade into the process. \| Such a position would have put him at odds with his prime minister (Washington Post, 22 January 2015).

The process, in this example, is viewed as a container. The grenade is viewed as a light moving object that could be thrown into a container. The process is the container into which the object thrown. Here, the container is an empty bounded hollow space into which the materials are put or thrown.

\section{OBSTACLES TO ACTION ARE OBSTACLES TO MOTION}

\section{Source Domain: motion Target Domain: obstacles}

Moving objects on the road face obstacles that make them get in the way of their moving forward. People face difficulties in life as well, but they have to remove and overcome the things they encounter. So the qualities of obstacles facing the moving objects are mapped onto the difficulties encountering people in life. Consider the following examples:

1. Netanyahu is expected to offer up a harder-line view, supported by many Republicans and some Democrats, that the threat of more sanctions is needed to blunt Iran's ambitions to build a nuclear weapon (Washington Post, 22 January 2015).

2. But Republicans have challenged the actions, calling them unconstitutional. The lawsuit from 25 states, led by Texas, argues that the "unilateral suspension of the Nation's immigration laws is unlawful." (Washington Post, 23 January 2015).

3. But Monday's vote was more a speed bump than a roadblock; both parties are expected to continue hashing out their differences on the bill (Washington Post, 26 January 2015).

In (1), the sanctions become hindrance to Iran's ambitions to go forward. They make them move forward slowly and lag behind the point which Iran wants to reach. In example (2), the Republicans pose the challenges to the actions by 25 statesthe lawsuit. The Republicans suspend the decision to be made by 25 states. Here the Republicans become obstacles to the 25 states' law on immigration. In example (3), Monday's vote is viewed as an obstacle to the continuing discussion of the differences among the parties. It is a speed bump put across the path to keep the situation move forward slowly.

By considering the examples above, we conceptualize the entities whether they are abstract or concrete; they become obstacles in moving forward the projects or any other suggestions. That's the way we face in life. This schema is at work in seeing life is a journey. In life, there are so many obstacles as we see in journeys.

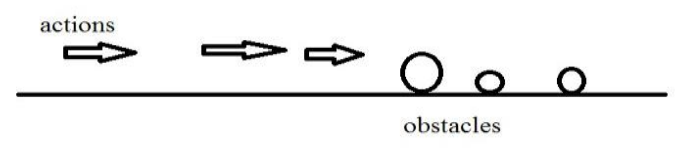

Figure.8 OBSTACLES TO ACTION ARE OBSTACLES TO MOTION

6. Existence Metaphor

\section{MAINTAINING EXISTENCE IS MAINTAINING LOCATION UP HERE}

Source Domain: Maintaining location:

Maintaining existence
Target Domain: 
To keep an object stay existent, it needs to exist in a place, it calls for a strong prop to hold it and to stand still. Look at the following examples

1. It [The group 99Rise] asked for support for the -Supreme Court 7.|l (Washington Post, 21 January 2015).

2. We continue to stand by his testimony (Washington Post, 23 January 2015).

In example (1), the Supreme Court requires the public or any group to support it to keep carrying out its duty and stay independent and keep away from any intervention outside law. In (2), to continue to stand by his testimony is to make the testimony stay as it is. Here the existence of the testimony is the goal to which they try to achieve and continue.

The examples above imply that maintaining the existence of something is treated as an object putting somewhere and trying to protect its existence in its own shape and style. Let it be as it is, preventing to let it fall down.

\section{EXISTENCE IS AN OBJECT}

\section{Source Domain: Object Target Domain: Existence}

When something come out of something else or is made of something, then it has existence. It is seen as an object. Existence is shown and treated as an object. It is true that we make objects out of the materials available to us. Here are some examples to disambiguate the matter:

- $\quad$ They [the mayors] made the announcement at the U.S. Conference of Mayors, which is taking place in Washington (Washington Post, 23 January 2015).

- This is a new thing, spotlighting the leadership and ridiculing the leadership. In any authoritarian, totalitarian system, that is an Achilles heel, \| Darusman said in an interview in Tokyo, where he held talks with the government on an investigation into North Korea's abductions of Japanese citizens (Washington Post, 23 January 2015).

- Obama announced in November that he would use his executive powers to protect as many as 4 million illegal immigrants from deportation and make other changes to border control policies designed to focus federal resources on violent and repeat criminals (Washington Post, 23 January 2015).

To put it in a nutshell, the existence and emergence of any abstract concept is treated as an object that can be made, used, etc.

\section{EXISTENCE IS VISIBILITY}

Source Domain: Visibility

Target Domain: existence

Existence is regarded as a visible thing that comes into sight when it appears. Ideas, situations, accidents, etc. have the same condition. Consider the following samples:

1. She said most of the disrupted plots appeared to be inspired or directed by terrorism overseas (Washington Post, 23 January 2015).

2. But Grimes emerged as one of the standout fundraisers of the midterms, stirring talk that she might seek a run for Kentucky's open governor's seat in 2015 (Washington Post, 26 January 2015).

In example (1), the disrupted plots come into view and existence; therefore, they are inspired and directed by terrorism overseas. In (2), Grimes's existence in the occasion is measured as his appearance in the situation. So his emergence as one of the standout fundraisers of the midterms is conceptualized as his existence. His existence is the visible matter to have his say.

\section{Human Metaphor}

From the data, we see that the human body is conceptualized as entities that support to stand firm like buildings. The human body is likened to rivers, substances, and plants. The features of these source domains are mapped onto the humans. Consider the following:

\section{PEOPLE ARE BUILDINGS}

\section{Source Domain: Buildings Target Domain: People}

Buildings are well structured in order that their parts will be connected to one another and stand firm. Buildings have walls, roofs, and pillars which are the backbones of the house, and there are some other parts to support the house, and so the people. They will become the prop and support for things. Sometimes, things will be support for them. Consider the following samples:

- The entire state structure has disintegrated in Anbar province. The tribal structure is not the same as when we were there ... Even a prominent tribal sheikh can issue an edict and not everyone, not the teenagers, are going to listen. \| (The Guardian, 19 December 2014).

- I support decentralisation. This is centralisation in an English parliament of 83\%. ॥ (The Guardian, 16 December 2014).

- $\quad$ Kurdish peshmerga forces backed by US-led air strikes pushed Islamic State militants out of a large area around Mount Sinjar in northern Iraq, according to Kurdish officials (The Guardian, 21 December 2014). 
TABLE. 3

MAPPINGS FOR PEOPLE ARE BUILDINGS

\begin{tabular}{ll}
\hline \hline PEOPLE = Target Domain & BUILDING= Source Domain \\
\hline Body & structure \\
Leg & Wall, support \\
Foot & foundation \\
back & pillar \\
\hline \hline
\end{tabular}

\section{PEOPLE ARE SUBSTANCES}

\section{Source Domain: Substances Target Domain: People}

People are considered to be substances because they receive features from substances. Substances can be extended, thrown, boiled, scattered, removed from somewhere, etc. the same situations could happen to people as seen in the following examples:

- But more protesters were scattered among the spectators who had waited in line to view the court's proceedings (Washington Post, 21 January 2015).

- Netanyahu is expected to offer up a harder-line view, supported by many Republicans and some Democrats, that the threat of more sanctions is needed to blunt Iran's ambitions to build a nuclear weapon (Washington Post, 22 January 2015).

In example (1), protesters are scattered and distributed like as the substances may be scattered on the ground or thrown somewhere. The scattering quality of a substance mapped onto the protesters. In (2), a harder-line view is supported by humans as if the humans are substances that are used to make something firm and fixed. This property of the materials is transferred to people to play the role of the substances. We see that the characteristics of the substances, which are typical of materials, can be transmitted from it to the people.

TABLE. 4

MAPPINGS FOR PEOPLE ARE SUBSTANCES

\begin{tabular}{ll}
\hline \hline People $=$ Target Domain & Substance $=$ Source Domain \\
\hline separating & scattering \\
helping & supporting \\
\hline
\end{tabular}

\section{HUMANS ARE RIVERS}

\section{Source Domain: Rivers Target Domain: Human}

It is heard from the news that some parts of the world are covered with heavy rain pouring down resulting in serious damage to a large number of buildings, crops, cars, etc. humans take on the qualities of the rivers. Look at the followings:

1. They were committed to this and we could see fighters flooding in from Raqqa and we saw that as an opportunity to attrite their manpower, $\|$ he said (The Guardian, 19 December 2014).

2. The official said it was too soon to tell whether the rate of attrition among Isis fighters had stemmed the flow of jihadi volunteers from abroad. The US is seeking to cut the flows from the home countries of the volunteers and at the main point of transit, the Turkish border (The Guardian, 19 December 2014).

In examples (1 and 2), fighters, like river, flooding try to wear down their enemies and remove the obstacles so that they can move forward. Rivers when flooding remove the trashes, waste materials, houses, cars, etc. from the place into which they flow. These features are mapped onto humans from the source domain to the target domain.

TABLE. 5

MAPPINGS FOR HUMANS ARE RIVERS

\begin{tabular}{ll}
\hline \hline Humans = Target Domain & Rivers = Source Domain \\
\hline Crowding, gathering & flooding \\
Walking & flowing \\
jumping & The tide going out \\
attacking & storming \\
\hline \hline
\end{tabular}

\section{HUMANS ARE PLANTS}

Source Domain: Plants Target domain: Humans

Plants have roots, branches, leaves, etc. they drink water. They grow and fall. They are cut down and rooted out by people or with violent storms. Humans are like that. Follow the example below:

- That means they [fighters] have got to be rooted out by ground troops. This has to be done by an own-grown army, not by western groups. \| (The Guardian, 13 December 2014).

In the example, the fighters are rooted out, like plants. This feature of plants is mapped onto the humans. Humans grow up, are planted and rooted out. Both humans and plants have communal properties. 
TABLE. 6

MAPPINGS FOR HUMANS ARE PLANTS

\begin{tabular}{ll}
\hline \hline Humans = Target Domain & Plants = Source Domain \\
\hline hands & leaves \\
Body, back & stem \\
foot & root
\end{tabular}

\section{LINEAR SCALES ARE PATHS}

Source Domain: paths Target Domain: scales, linear scales

But Republicans have challenged the actions, calling them unconstitutional. The lawsuit from 25 states, led by Texas, argues that the "unilateral suspension of the Nation's immigration laws is unlawful." (Washington Post, 23 January 2015).

1. We continue to stand by his testimony. The fact that he came out clarifying his earlier statement and corrected his timelines of events does not in any way affect the integrity and neither credibility of the report nor the thrust of its recommendations, \| Darusman told reporters in Tokyo earlier Friday (Washington Post, 23 January 2015).

2. The president said he acted after Congress failed to approve a comprehensive immigration reform bill last summer (Washington Post, 23 January 2015).

3. Although China's military capabilities lag far behind those of the United States, its defense spending is growing by double-digit percentages annually (Washington Post, 2 February 2015).

4. Overturn Citizens United, $\|$ one shouted, referring to the court's 2010 decision in Citizens United v. Federal Election Commission. That, along with subsequent court rulings, has greatly expanded the amounts that individual and corporate interests may spend on election campaigns (Washington Post, 21 January 2015).

In example (1), Twenty-five states are going on a road. The states are led by Texas, so Texas is the leader of the states. It is ahead of them, and the others are behind the leader. In example (2) earlier statement signals that there are some statements made by Darusman but the one he is clarifying is the earlier one. So, the statements are ordered in sequence, but the one he means is before the specific one. They are in a linear scale ordered in sequence. In example (3), the president's act is after congress's failure attempt. Here, the failure is a specific point and other incidents are viewed from the perspective of congress's failure; therefore, the president's act is after the failure. In example (3), China's military capabilities are taking part in a race against those of United States. Those of China's are behind those of US. They are late in competing with the opponent. In example (4), there are court rulings; the court's decision in 2010 is nearly at the end of the series of rulings issued by the court. Here, the rulings are regarded as a path, and the court's 2010 decision is expanded along this road in a linear level on the road. It is located in the succeeding rulings of the court.

From the examples above we deduce that we conceptualize entities according to a line in which it has beginning and middle and end. We specify a point in the line, and we see whether the entity is before or after the line.

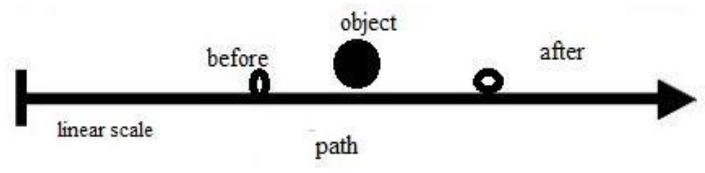

Figure.9 LINEAR SCALES ARE PATHS

\section{Substance Metaphor}

The items which are not basically material or substance, like abstract things, are conceptualized as substance. They take on the features of the substance as they are illustrated below:

\section{CHANGE OF STATE IS CHANGE OF SHAPE}

Source Domain: Change of shape Target Domain: Change of state

When a solid material changes into gas, the shape of the material changes then, as in the case of water. When it is heated, it evaporates and changes into gas. Or when it is poured into a glass, it picks up the shape of the glass. Consider the following instances:

1. Darusman, echoing Michael Kirby, the Australian judge who led the commission, said Shin was just one of more than 200 witnesses who testified and that slight changes in his story did not dent the totality of the evidence that the commission had collected (Washington Post, 23 January 2015).

2. Although China has made no secret of its desire to expand its navy and add to its sole aircraft carrier (Washington Post, 2 February 2015).

In example (1), the totality of the evidence is dented and bent inwards, when dramatic changes happen to it. Thus, the totality of the evidence depends on the factor that changes the shape. Hence, there is great coherence between the change of state and the change of shape. These properties are mapped from source domain onto target domain as a result. When things are expanded, their shapes are changed as in (2). The structure of the navy is changed when expanded.

Substances have, by definition, some features such as the ability to expand, enlarge, shorten, etc. these qualities are mapped onto the target domain-navy. Navy has the capacity to expand, here. It takes on the qualities of substance via mapping. Hence, the navy is likened to substance. 


\section{ACTIONS ARE ENTITIES}

Source Domain: Entities:

Target Domain: Actions

Entities are the existing materials that can be counted, pressed down, broken, etc. Some of the characteristics entities have can be mapped onto the actions. Consider the followings:

1. Scott Pruitt, Oklahoma's attorney general, said Monday he was asking the U.S. Supreme Court to postpone three executions in his state that are scheduled over the next six weeks, with the first set for Thursday (Washington Post, 26 January 2015).

2. Senate Democrats stalled the Republican-led push to construct the Keystone XL Pipeline on Monday, dealing the first significant blow to the new Republican majority less than three weeks after being sworn in (Washington Post, 26 January 2015).

In example (1), three executions take on the features of entities. The executions have the quantity in number - three executions. They are similar to the entities being countable. In (2), the blow takes the number one comparing to other actions prepared to be carried out. It is number one. It is conceptualized as an entity as a result.

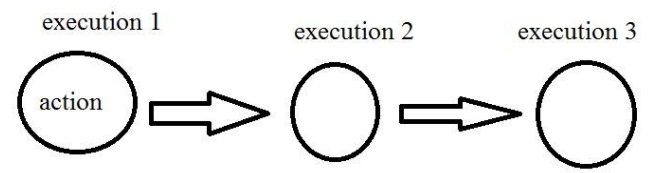

Figure.10 ACTIONS ARE ENTITIES

\section{Talk Metaphor}

Talk represents different things in the examples discovered in the data. It is likened to various entities as it is explained below:

\section{TALK IS A PROCESS}

Source Domain: Process

Target Domain Talk

Process is a string of events or actions connected to each other happening one after the other, and it gives rise to a particular result. It takes place across along a road. The process has beginning, middle, and end. It is sometimes static or nonstop. It depends on the way the process occurs in a particular situation. The process's features are mapped onto the talks. Consider the following examples:

1. The talks have begun on a low key, without Kerry or Zarif or any of the other foreign ministers for the time being (The Guardian, 15 December 2014).

2. As the International Crisis Group points out in its comprehensive assessment of the talks, Iran Nuclear Talks: The Fog Recedes, this was an essential procedural short- cut that was agreed at the end of the Vienna talks (The Guardian, 15 December 2014).

In example (1), the talks have begun on a small event-it is still at the beginning of a process. In (2), the talks are at the end of the process. They are taking the final steps of the process, and they are about to finish.

In a nutshell, the process has some features which are mapped onto the talks. The talks take on these qualities that can be applied in different activities.

\section{TALK IS A BRITTLE OBJECT}

Source Domain: A brittle object

Target Domain: Talk

Brittle objects are easily damaged and broken down. They need to be well looked after lest they can break down. For the talks the same could happen. Consider the example below:

- Such a move, Obama has said, would cause the delicate talks with Iran to fail and increase the likelihood of armed conflict (Washington Post, 22 January 2015).

The talks between US and Iran are likely become worse. They are about to come a standpoint; therefore, their talks are delicate, they are shaky. The talks take on the features of the brittle object.

\section{PSYCHOLOGICAL IMPACT FORCES ARE PHYSICAL IMPACT FORCES}

\section{Source Domain: Psychological Impact Forces}

Target Domain: Physical Impact Forces:

One of the devices that opponents use is the psychological means which is put into use during the conflict provoked between them. For example, the superpowers hand out punishments to other countries resulting from the violation of international rules. Here, the characteristics of psychological impact are displayed as physical impact, i.e., as if they were physically harmed by using physical objects and having visible results consequently. Reflect on the following examples:

1. Thomas said: -George Osborne's plans for cuts in Metropolitan police funding ... would have a devastating impact on the quality of policing in London and be the final death knell for high visibility, bobby-on-the-beat local policing.\| (The Guardian, 22 December 2014).

2. A veto would upset Palestinians and perhaps some Arab allies frustrated by years of diplomatic gridlock. Several are fighting alongside the US against the Islamic State (The Guardian, 15 December 2014).

In example (1), Osborne's plan is viewed as a big object that has the ability to devastate the quality of policing in London due to having the impact on the quality. In (2), the veto is regarded 
as a force to psychologically upset and annoy Palestinians. They consider the veto as a force which is going to return them to the first point. They again start negotiating with Israel. This result in wasting more time to declare the Palestinian independent state, but the problem is the veto by some countries which upset the Palestinians. From the above example, we can perceive that psychological forces are used in a way that has physical results.

\section{IMPORTANCE IS PRECEDENCE}

Source Domain: Precedence Target Domain: Importance

Everything is almost, in life, ordered according to importance, i.e., the most important things take priority over the less ones and so on. Look at the following samples:

1. The first duty of any government is the safety and security of its citizens (The Guardian, 22 December 2014).

2. But more important than the people is the process. This time the talks have quickly entered their most effective forum, bilateral encounters between the Americans and the Iranians (The Guardian, 15 December 2014).

In example (1), the safety and security of its citizens are the most important duties of the government to fulfill at first. They are taken high priorities. They need more attention over others. In (2), the process takes precedence over the other issues for being important for both the Americans and the Iranians in bringing closer the two sides.

\section{AGREEMENT IS A JOURNEY}

Source Domain: Journey Target Domain: Agreement

Journeys have some features that are mapped onto target domain, agreement. In journeys, we encounter obstacles, difficulties, long paths, being tired, etc. In journeys; we want to get a point. We have a goal. The agreement takes on these features. Consider the followings:

1. Now we know, more or less, the scale and nature of the obstacles that prevented them clinching an agreement (The Guardian, 15 December 2014).

2. After failing to reach agreement in Vienna by a November 24 deadline after nine months of negotiations, diplomats are sitting down in Geneva today to try to keep the momentum for a nuclear deal going (The Guardian, 15 December 2014).

In example (1), the agreement faces obstacles which do not let it make progress. In (2), to reach agreement is like to reach a goal that you are going to move towards it. Here, the agreement does not achieve the goal, it fails. That is a difficulty facing the agreement in its movement to go forward.
We see through the above examples that agreement is conceptualized as journeys. In journeys, we have a goal, and we sometimes face difficulties preventing us from reaching the goal. So, does the agreement. The properties are mapped onto the agreement.

TABLE.7 MAPPINGS FOR 4.2.13 AGREEMENT IS A JOURNEY

\begin{tabular}{ll}
\hline \hline Agreement $=$ Target Domain & Journey = Source Domain \\
\hline negotiators & travellers \\
Disagreement, quarrel & obstacles \\
conclusion & destination \\
\hline \hline
\end{tabular}

10. Other conceptual metaphors

In the data collected from the online newspapers, it can be found some conceptual metaphors occur infrequently. Each of them play one part in the data as it is described in below samples:

\section{THE RELATIONSHIP IS A HEAVY OBJECT}

Source Domain: A Heavy Object

Target Domain: The Relationship:

Relationships are conceptualized in different ways. Here, it is viewed as a heavy object that is firm and fixed which is difficult to lift, push or remove from somewhere. Consider the example below:

- The bilateral relationship is unshakable, \| said a source close to Kerry. - But playing politics with that relationship could blunt Secretary Kerry‘s enthusiasm for being Israel's primary defender.\| (Washington Post, 22 January 2015).

In the example, the relationship is considered as a heavy object. It is unshakable, it cannot be lifted because it is difficult to move-it needs much energy and strength. Here the relationship has the same condition as a heavy object has. The relationship is in the state of being firm and steady between the two sides. They have a good relationship with each other. So, the relationship takes on the features of the heavy object.

\section{REFORMS ARE PATHS}

Source Domain: Paths

Target Domain: Reforms

Paths usually have a beginning, middle, and an end. Paths pick up different shapes such as wide, narrow, steep, high, and low. 
Paths sometimes are rocky, muddy, etc. Some of these qualifications can be mapped onto the reforms. Reflect on the following sample:

- Graham Allen, the Labour chairman of the public administration select committee, also criticised the narrow scope of the Hague reforms, saying: - The real debate is not about House of Commons procedure but about how local government can be the vehicle of devolution in England (The Guardian, 16 December 2014).

In the above example, the Hague reforms have the narrow scope that does not let the system in the parliament be improved and made changes. Here the road is narrow. It is too difficult to go across carrying a heavy bag, for example. The condition applies to the reforms. Making changes becomes a difficult task when the reforms have a narrow scope.

\section{DEBATE IS HOT FLUID}

\section{Source Domain: Hot Fluid}

Target Domain: Debate

Fluid is an entity that has the ability to be heated, boiled, evaporated, and melted when it is solid. Consider the following example:

- House Speaker John A. Boehner invited the Israeli leader to speak to Congress amid a heated debate over whether new sanctions, to be imposed if talks fail, would scuttle tenuous negotiations with Iran over its nuclear program (Washington Post, 22 January 2015).

In the example, the debate is realized as a fluid which becomes heated as fire is used to make it hot. The debate is heated when different people who have different attitudes over discussing issues to offer good solutions to problems facing their government. Different viewpoints are put forward from several angles with which they interact each other, and then the debate among them is heated, like fluid. So, the properties of the fluid are mapped onto the debate.

\section{MOVEMENT IS A STRUCTURE}

\section{Source Domain: Entities}

Target Domain: Actions

Buildings are structured in a way that their different parts are strictly organized and ordered, and they are built with blocks so that all parts of the wall can be connected to one another firmly lest they may collapse and have tragic consequences. Consider the following example:
- $\quad$ The group 99Rise, which said on its Web site that it is "building a nationwide movement to get big money out of American politics through nonviolent action, ॥ said it was responsible for the protests (Washington Post, 21 January 2015).

Here, in the example above the movement to get a large amount of money is realized as the structure a building which is going to be constructed. The properties of structure are mapped onto the source domain, i.e., the substance. The movement should be fixed and stable in order that it can confront unpleasant conditions which may happen.

\section{MISSIONS ARE SWEEPERS}

\section{Source Domain: Sweepers Target Domain: Missions}

Sweepers clean places off the marks, dirt, unnecessary materials, trashes, and anything which are not used any longer, and they are thrown away. When a road is blocked off with a fallen tree preventing people from crossing it, people try to remove the obstacle to let them go. Mission plays the same role. Consider the following:

- $\quad$ For months the US air force and RAF planes have been heavily involved in air strikes and reconnaissance missions across Iraq that are credited with helping slow the advance of ISIS fighters and have now paved the way for ground operations (The Guardian, 13 December 2014).

In the example, air strikes and reconnaissance missions across Iraq are sweepers. They remove the ground from the advance of Isis fighters so that the ground will be ready to carry out the ground operations. The missions are paving the way from the Isis fighters. Here, both the missions and sweepers share some features such as removing, cleaning, brushing, etc. the features from the sweepers are mapped onto the missions.

\section{PLACES ARE SIZES}

Source Domain: Sizes

Target Domain: Places

Sizes have various shapes such as middle, small, big, large, etc. So do places which they bear resemblances to sizes. Consider the following:

- A group of big-city mayors led by New York's Bill de Blasio and Los Angeles's Eric Garcetti announced plans (Washington Post, 23 January 2015). 
In the example, the city is conceptualized as shapes having big size - the big city. The city features of sizes. Here, we reach a point that two different things can be likened to one another due to having the features of mapping between them.

\section{RESUltS AND FINDINGS}

After examining the data and the results discussion, study has come up with some major findings as outlined below:

The spatial metaphor controls the largest distribution of the data by 59 which makes $34.3 \%$ of the total data. This may be due to the fact that humans lead most of their life experiencing space and locations. For example, moving from place to place, travelling, driving, etc. humans move more frequently rather than think.

The researchers believe that human interaction with their fellow human beings is so recurrent and widespread that personification metaphors come second only to the spatial category because human beings are, by nature, social creatures who find it hard to lead an isolated life particularly nowadays in the age of communication.

Causation metaphor comes third in the category. This is for the reason that human beings conceptualize political issues in terms of wars, change of state, creating, and substance associating with organizing physical and cultural realities.

Temporal metaphors occupy the fourth type in the category. This may result from the fact that time is not of much importance to the politicians.

Container metaphors come next in the table. This results from that human beings are physical beings that are covered with skins leading to being kept apart from the rest of the world, and other beings are viewed as containers. Moving from house to house is container coming out into another. In the data, places, forces, products, processes, and votes are seen as containers having in-out orientations.

Obstacles, existence, and human metaphors share somehow similarities among the news reports resulting from the way we construe the frequency of the events taking place around us. They take an average level in the table.

\section{CONCLUSIONS}

Based on the findings of the study, the following conclusions have been drawn from the study:

1. Conceptual metaphors are pervasive in political news reports, be they from Britain or the United States' newspapers. Noticeably, some conceptual metaphors are more frequent than the others such as SPATIAL, PERSONIFICATION, and TEMPORAL metaphors respectively.

2. Our study has confirmed that spatial metaphors occur most. This may be due to the fact that humans lead most of their life experiencing space and locations. For example, moving from place to place, travelling, driving, etc. humans move more frequently rather than think.

3. Personification metaphors also occur very frequently which could be attributed to the fact that human beings are, by nature, social creatures who find it hard to lead an isolated life particularly nowadays in the age of communication.

4. Causation metaphor and temporal metaphors come in between the two extremes. The former's occurrence is likely to be accounted for as that human beings conceptualize political issues in terms of wars, change of state, creating, and substance associating with organizing physical and cultural realities. However, the latter's occurrence is likely to be ascribed to the fact that time is not of much importance to the politicians.

5. Container, obstacles, existence, and human metaphors are viewed as representing the other least frequent extreme as they share somehow similarities among the news reports resulting from the way we construe the frequency of the events taking place around us. They take an average level in the table.

\section{REFERENCES}

Abrams, A. (1999). A Glossary of Literary Terms. 7th ed. Boston, MA: Heinle \& Heinle.

Conboy, M. (2007). The Language of News. London: Routledge.

Cruse, A. (2006). A Glossary of Semantics and Pragmatics. Edinburgh: Edinburgh University Press.

Day, D., Jordan, P. and Wingate, J. (2017). Substance Metaphor. [online] SIL Glossary of Linguistic Terms. Available at: http://www.glossary.sil.org/term/substance-metaphor [Accessed 14 Jul. 2014].

Evans, V. and Green, M. (2006). Cognitive linguistics. Edinburgh: Edinburgh University.

Galperin, I. (1977). Stylistics. Moscow: Higher School.

Kövecses, Z. (2008). Conceptual metaphor theory: Some criticisms and alternative proposals. [online] Academia.edu. Available at: http://www.academia.edu/5452404/Conceptual_metaphor_th eory_Some_criticisms_and_alternative_proposals [Accessed 18 Oct. 2014].

Kövecses, Z. (2010). Metaphor: A Practical Introduction. 2nd ed. Oxford University Press: Oxford University Press. 
Lakoff, G. and Johnson, M. (1980). Metaphors we live by. Chicago: Univ. of Chicago Press.

Lakoff, G. and Johnson, M. (1980). The Metaphorical Structure of the Human Conceptual System. Cognitive Science, [online] 4(2), pp.195-208. Available at: http://onlinelibrary.wiley.com/doi/10.1207/s15516709 $\operatorname{cog} 040$ 2_4/pdf [Accessed 1 Nov. 2014].

Lakoff, G. (1987). Women, fire, and dangerous things. Chicago (Ill.): University of Chicago Press.

Lakoff, G. (1993). The Conduit Metaphor: A Case of Frame Conflict in Our Language about Language. In: A. Ortony, ed., Metaphor and Thought. Cambridge: Cambridge Univ. Press.

Lakoff, G. (1993). The Contemporary Theory of Metaphor. In: A. Ortony, ed., Metaphor and Thought. Cambridge: Cambridge Univ. Press.

Lakoff, G. (2009). The political mind. New York: Penguin Books.

LAKOFF, G. (1990). The Invariance Hypothesis: is abstract reason based on image-schemas?. Cognitive Linguistics, [online] 1(1), pp.39$74 . \quad$ Available at: https://georgelakoff.files.wordpress.com/2014/11/invariancehypothesis-lakoff-1990.pdf [Accessed 1 Apr. 2015].

Liu, X. and Zhao, G. (2013). A Comparative Study of Emotion Metaphors between English and Chinese. Theory and Practice in Language Studies, [online] 3(1). Available at: https://pdfs.semanticscholar.org/4a28/31dbe86eb4073184560 2c56d2daf3b0ebcfe.pdf [Accessed 13 Nov. 2013].

Richards, I. (1936). The philosophy of rhetoric. Oxford: Oxford University Press.

Ruiz de Mendoza Ibáñez, F., de Mendoza Ibáñez, F. and Hernández, L. (2011). The Contemporary Theory of Metaphor: Myths, Developments and Challenges. [online] Academia.edu. Available at: http://www.academia.edu/2061405/The_Contemporary_Theo ry_of_Meta phor_Myths_Developments_and_Challenges [Accessed 10 Mar. 2015].

Saeed, J. (2009). Semantics. New York, NY: John Wiley \& Sons.

Tendahl, M. (2009). A hybrid theory of metaphor. Basingstoke: Palgrave Macmillan.

Websites consulted:

www.theguardian.com/uk

www.washingtonpost.com/

\section{APPENDIX}

THE GUARDIAN SAMPLES

\section{HIGH STATUS IS UP, LOW STATUS IS DOWN}

1. Peshmerga forces launched an operation to liberate some important areas in Sinjar and Zumar at 7am (04.00 GMT)," a peshmerga brigadier general said (Guardian, 17 December 2014).

2. "The plan to liberate Sinjar was reviewed by the Kurdish leader and the peshmerga field commanders. God willing, we will liberate it soon," Fuad Hussein said (Guardian, 17 December 2014).

3. Since some laws, although almost exclusively applicable to England, have a knock-on effect for Scotland as the junior economic partner in the union (Guardian, 16 December 2014).

4. The officials say air strikes since mid-November have killed senior and mid-level leaders as well as about 1,000 fighters, particularly around the fiercely contested Kurdish town of Kobani on the SyrianTurkish border (Guardian, 19 December 2014).

5. Graham Allen, the Labour chairman of the public administration select committee, also criticised the narrow scope of the Hague reforms, saying: "The real debate is not about House of Commons procedure but about how local government can be the vehicle of devolution in England....(Guardian, 16 December 2014).

6. "We are ready, we are waiting for the advancing forces from Rabia and Zumar," said Dawood Jundi, a field commander with the peshmerga (Guardian, 17 December 2014).

\section{MORE IS UP, LESS IS DOWN}

7. Internationalisation face losing their jobs by the end of the decade as part of George Osborne's plans to shrink the size of the state, according to a Labour analysis of figures compiled by the House of Commons library (Guardian, 22 December 2014).

8. On Labour's analysis, if the Met had to cut its budget by $£ 100 \mathrm{~m}$ in $2016-7$, it would have to trim police numbers by 1,298 if it relied on officer headcount reductions alone to achieve that level of saving. If the same level of saving was required for each of the four years, 194 posts could be at risk (Guardian, 22 December 2014).

9. Kerry's sudden involvement in talks around the resolution is being seen as an attempt to manage a process the US fears could raise already high tensions and in which according to one quoted official it sees only "bad scenarios" (Guardian, 15 December 2014).

10. If there are fewer police, they will have to rely on people phoning as a result of an emergency rather than 
getting access to that intelligence (Guardian, 22 December 2014).

11. The majority of those trapped on the mountain fled when Kurdish forces opened a corridor but, four months on, little has improved for those who are still on the mountain (Guardian, 17 December 2014).

12. Last month General Martin Dempsey, the most senior officer in the US military, revealed that the US is actively considering the direct use of troops against Isis in Iraq, days after Barack Obama doubled troop levels there (Guardian, 13 December 2014).

13. Fallon revealed that the RAF had flown a "huge number" of missions above Iraq second to the United States and five times as many as France (Guardian, 13 December 2014).

14. Thousands of UK police officers The Labour MP Graham Allen said the esca,lation represented exactly the kind of mission creep opponents of the initial engagement had feared and suggested MPs be asked again to give their approval (Guardian, 13 December 2014).

15. Specifically excluded from the Commons motion approving action to Iraq (Guardian, 13 December 2014).

16. While Labour hides from reform because it hopes its Scottish MPs will ensure it retains an overall Commons majority (Guardian, 16 December 2014).

17. Internationalisation face losing their jobs by the end of the decade as part of George Osborne's plans to shrink the size of the state, according to a Labour analysis of figures compiled by the House of Commons library (Guardian, 22 December 2014).

18. On Labour's analysis, if the Met had to cut its budget by $£ 100 \mathrm{~m}$ in $2016-7$, it would have to trim police numbers by 1,298 if it relied on officer headcount reductions alone to achieve that level of saving. If the same level of saving was required for each of the four years, 194 posts could be at risk (Guardian, 22 December 2014).

19. The experience in this parliament - in which we've cut spending by $20 \%$ and crime has fallen by more than a fifth - shows that it's possible to do more with less." (Guardian, 22 December 2014).

20. Kuwait has agreed to defer next year's Iraqi reparations payment dating to Saddam Hussein's 1991 invasion, which would reduce Baghdad's costs by $\$ 4$.6bn, helping compensate for the slump in oil prices and allowing more to spend on building up loyalist forces to combat Isis (Guardian, 19 December 2014).

21. Labour boycotted the interparty talks largely because it wanted the issue discussed at greater length and in the round, including the implications for the future of the House of Lords (Guardian, 16 December 2014).
22. The US-led coalition air strikes, which began in early August, have intensified over the past 20 days after Kurdish ground forces began attacking Isis positions in Sinjar areas (Guardian, 21 December 2014).

23. On Saturday night on Mount Sinjar, the air strikes continued non-stop for more than 12 hours on Isis positions, some of which were visible from the mountain top. Peshmerga fighters there told the Guardian that the past two days had seen the most intensive bombing so far (Guardian, 21 December 2014).

24. Kerry's sudden involvement in talks around the resolution is being seen as an attempt to manage a process the US fears could raise already high tensions and in which according to one quoted official it sees only "bad scenarios" (Guardian, 15 December 2014).

\section{FALLING IS DOWN, RISING IS UP}

25. However, the French proposal is seen by Palestinians as falling far short of their demands (Guardian, 15 December 2014).

26. A Pentagon spokesman, Rear Admiral John Kirby, said the deaths had degraded its "command and control current operations" (Guardian, 19 December 2014).

\section{INSTITUTIONS ARE SPEAKERS}

27. The Guardian reported that the Met needed to find an extra $£ 800 \mathrm{~m}$ of cuts in the next budget period, from 2016-2020 (Guardian, 22 December 2014).

\section{PLACES ARE PSYCHOLOGICALLY AFFECTED}

28. The Commons library is impartial and does not endorse individual party policies. It carries out research on behalf of MPs, including frontbenchers (Guardian, 22 December 2014).

29. The US is using Turkish bases for intelligencegathering purposes but Ankara remains reluctant to allow its bases to be used for launching bombing sorties (Guardian, 19 December 2014).

\section{PLACES ARE PRISONERS}

30. Peshmerga forces launched an operation to liberate some important areas in Sinjar and Zumar at 7am (04.00 GMT)," a peshmerga brigadier general said (Guardian, 17 December 2014).

31. Yazidi fighting units that were formed in the wake of the August attack have struggled to control land in the Sinjar area and retreated to the mountain once again in September (Guardian, 17 December 2014).

32. Iraqi Kurdish forces launched a broad offensive on Wednesday aimed at recapturing areas near the Syrian border that have been held by Islamic State (Isis) for months, officials said (Guardian, 17 December 2014). 
33. A senior US official said Isis had suffered particularly high casualties as a result of its determination to capture Kobani, sending many fighters to the border town, where they could easily be targeted by US planes (Guardian, 19 December 2014).

34. Peshmerga forces launched an operation to liberate some important areas in Sinjar and Zumar at $7 \mathrm{am}$ (04.00 GMT)," a peshmerga brigadier general said (Guardian, 17 December 2014).

35. Yazidi fighting units that were formed in the wake of the August attack have struggled to control land in the Sinjar area and retreated to the mountain once again in September (Guardian, 17 December 2014).

36. Iraqi Kurdish forces launched a broad offensive on Wednesday aimed at recapturing areas near the Syrian border that have been held by Islamic State (Isis) for months, officials said (Guardian, 17 December 2014).

37. A senior US official said Isis had suffered particularly high casualties as a result of its determination to capture Kobani, sending many fighters to the border town, where they could easily be targeted by US planes (Guardian, 19 December 2014).

\section{CAUSES ARE FORCES}

38. Complicating the issue are several factors, not least the fact that Israel is at the beginning of a prolonged election campaign that diplomats believe will lead to a hardening of Netanyahu's position (Guardian, 15 December 2014).

\section{CAUSED CHANGE IS FORCED MOTION}

39. Internationalisation of the issue - several European countries have taken symbolic votes recognising a Palestinian state - has pushed some to speculate that the Washington is more open to engaging in talks about security council intervention (Guardian, 15 December 2014).

40. Among the goals is the Sinjar area, which was home to many members of the Yazidi minority before Isis attacked in early August and forced most of them to flee (Guardian, 17 December 2014).

41. It was partly the plight of the Yazidi people that forced Barack Obama and the international community into action against Isis (Guardian, 21 December 2014).

42. The latest victories for peshmerga forces and the recapture of northern Mount Sinjar have brought new hopes to the Yazidis who are still stuck on the mountain and want to go back to their villages (Guardian, 21 December 2014).

\section{CAUSES ARE MAKERS}

43. Downing Street dismissed Hogan-Howe's call for a reduction in the number of police forces, prompting fears that cuts will have to be introduced in other ways (Guardian, 22 December 2014).

\section{CAUSES ARE SUBSTANCES}

44. Speaking ahead of his trip to meet Kerry in Rome, Netanyahu said: "We will not accept attempts to impose unilateral measures upon us by a set date, at a time when radical Islam is spreading throughout the world." (Guardian, 15 December 2014).

\section{TIME IS A MOVING OBJECT}

45. The peshmerga had already recaptured three small villages, the officer added (Guardian, 17 December 2014).

46. The Palestinian president, Mahmoud Abbas, is pushing for a vote in the United Nations Security Council - as early as Wednesday - on a resolution calling for a deadline to end the 47-year-long Israeli occupation (Guardian, 15 December 2014).

47. Earlier this month, the Guardian reported that the Met needed to find an extra $£ 800 \mathrm{~m}$ of cuts in the next budget period, from 2016-2020 (Guardian, 22 December 2014).

\section{TIME IS A PATH}

48. The officials say air strikes since mid-November have killed senior and mid-level leaders as well as about 1,000 fighters, particularly around the fiercely contested Kurdish town of Kobani on the SyrianTurkish border (Guardian, 19 December 2014).

49. Internationalisation face losing their jobs by the end of the decade as part of George Osborne's plans to shrink the size of the state, according to a Labour analysis of figures compiled by the House of Commons library (Guardian, 22 December 2014).

TIME IS SUBSTANCE

50. The deadline was extended until the beginning of July 2015 , with the aim of agreeing a framework deal by March 1(Guardian, 15 December 2014).

\section{PLACES ARE CONTAINERS}

51. Since then, the continued devolution of further powers to Scotland and Wales has increased the call for matching devolution within England (Guardian, 16 December 2014).

52. At the same time, US advisers are operating alongside Iraqi trainers in Anbar province, helping train and organise Sunni tribesmen into regular units to confront Isis (Guardian, 19 December 2014).

\section{FORCES ARE CONATINERS}


53. This time, the Iraqi government will seek to absorb the Sunni units into the national security forces (Guardian, 19 December 2014).

54. At the same time, US advisers are operating alongside Iraqi trainers in Anbar province, helping train and organise Sunni tribesmen into regular units to confront Isis (Guardian, 19 December 2014).

55. Fallon said details of the contribution to an international mission were still being finalised but would likely include a small contingent of combatready British soldiers at four US-led "safe" centres, one in Kurdistan and three near the Iraqi capital Baghdad (Guardian, 13 December 2014).

\section{VOTE IS A CONTAINER}

56. The most radical of the three options involves nonEnglish MPs being excluded from all votes of an English-only nature, including the budget (Guardian, 16 December 2014).

\section{PEOPLE ARE BUILDINGS}

57. "The entire state structure has disintegrated in Anbar province. The tribal structure is not the same as when we were there ... Even a prominent tribal sheikh can issue an edict and not everyone, not the teenagers, are going to listen." (Guardian, 19 December 2014).

58. I support decentralisation. This is centralisation in an English parliament of 83\%." (Guardian, 16 December 2014).

59. Kurdish peshmerga forces backed by US-led air strikes pushed Islamic State militants out of a large area around Mount Sinjar in northern Iraq, according to Kurdish officials (Guardian, 21 December 2014).

\section{HUMANS ARE RIVERS}

60. "They were committed to this and we could see fighters flooding in from Raqqa and we saw that as an opportunity to attrit their manpower," he said (Guardian, 19 December 2014).

61. The official said it was too soon to tell whether the rate of attrition among Isis fighters had stemmed the flow of jihadi volunteers from abroad. The US is seeking to cut the flows from the home countries of the volunteers and at the main point of transit, the Turkish border (Guardian, 19 December 2014).

\section{HUMANS ARE PLANTS}

62. "That means they [fighters] have got to be rooted out by ground troops. This has to be done by an owngrown army, not by western groups." (Guardian, 13 December 2014).

\section{TALK IS A PROCESS}

63. The talks have begun on a low key, without Kerry or Zarif or any of the other foreign ministers for the time being (Guardian, 15 December 2014).

64. As the International Crisis Group points out in its comprehensive assessment of the talks, Iran Nuclear Talks: The Fog Recedes, this was an essential procedural short-cut that was agreed at the end of the Vienna talks (Guardian, 15 December 2014).

65. "The French are talking about a timeframe for a conclusion of peace talks (Guardian, 15 December 2014).

\section{PSYCHOLOGICAL IMPACT FORCES ARE PHYSICAL} IMPACT FORCES

66. Thomas said: "George Osborne's plans for cuts in Metropolitan police funding ... would have a devastating impact on the quality of policing in London and be the final death knell for high visibility, bobby-on-the-beat local policing." (Guardian, 22 December 2014).

67. A veto would upset Palestinians and perhaps some Arab allies frustrated by years of diplomatic gridlock. Several are fighting alongside the US against the Islamic State (Guardian, 15 December 2014).

\section{IMPORTANCE IS PRECEDENCE}

68. "The first duty of any government is the safety and security of its citizens (Guardian, 22 December 2014).

69. But more important than the people is the process. This time the talks have quickly entered their most effective forum, bilateral encounters between the Americans and the Iranians (Guardian, 15 December 2014).

70. Labour believes reducing police numbers would be a dangerous process. Under the A19 procedures, which are designed to protect their independence, police officers can only be removed for disciplinary reasons. The only way to do it is to require officers with at least three decades of experience to retire. This means that officers with experience would have to be targeted (Guardian, 22 December 2014).

71. He also suggested that a key element of the UK contribution would be passing on the experience gained during previous operations in Iraq - the last British troops to withdraw from the country left as recently as May 2011(Guardian, 13 December 2014).

\section{AGREEMENT IS A JOURNEY}

72. Now we know, more or less, the scale and nature of the obstacles that prevented them clinching an agreement (Guardian, 15 December 2014).

73. After failing to reach agreement in Vienna by a November 24 deadline after nine months of negotiations, diplomats are sitting down in Geneva 
today to try to keep the momentum for a nuclear deal going (Guardian, 15 December 2014).

74. It was expected that the major sticking points would be the scale of Iran's uranium enrichment capacity and the pace of sanctions relief (Guardian, 15 December 2014).

75. He is to put forward a range of different proposals, reflecting the inability of the parties to come to an agreement (Guardian, 23 December 2014).

\section{REFORMS ARE PATHS}

76. Graham Allen, the Labour chairman of the public administration select committee, also criticised the narrow scope of the Hague reforms, saying: "The real debate is not about House of Commons procedure but about how local government can be the vehicle of devolution in England.... (Guardian, 16 December 2014).

\section{MISSIONS ARE SWEEPERS}

77. For months the US airforce and RAF planes have been heavily involved in air strikes and reconnaissance missions across Iraq that are credited with helping slow the advance of Isis fighters and have now paved the way for ground operations (Guardian, 13 December 2014). 